
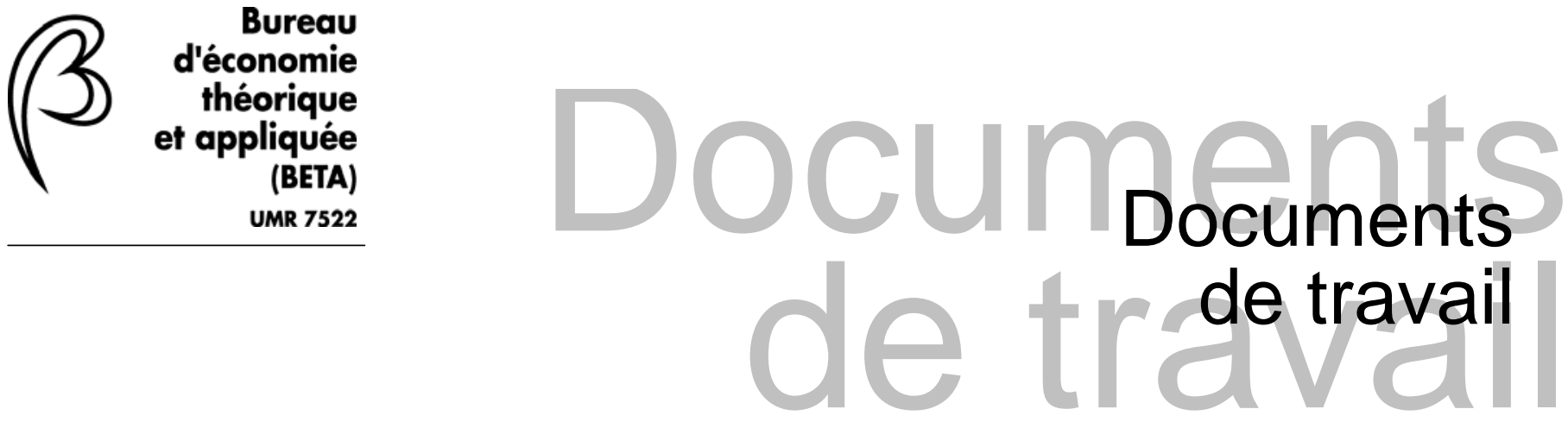

\title{
" Justifying the Origin of Real Options and their Difficult Evaluation in Strategic Management »
}

\section{$\underline{\text { Auteur }}$}

Thierry BURGER-HELMCHEN

Document de travail $n^{\circ}$ 2006-31

Octobre 2006

Faculté des sciences économiques et de gestion

Pôle européen de gestion et d'économie (PEGE)

61 avenue de la Forêt Noire

F-67085 Strasbourg Cedex

Secrétariat du BETA

Christine Demange

Tél. : (33) 0390242069

Fax : (33) 0390242070 demange@cournot.u-strasbg.fr http://cournot.u-strasbg.fr/beta 


\title{
Justifying the Origin of Real Options and their Difficult Evaluation in Strategic Management
}

\author{
Thierry BURGER-HELMCHEN*
}

\begin{abstract}
(131 words)
This work explores and reviews the introduction of real option in the strategic management literature. The aim is to contribute to a better understanding of the origin of the real option. By distinguishing between shadow and real option, and implementing entrepreneurship in the traditional option valuation framework we obtain a more exhaustive representation of the strategic decision processes in the firm. We explain the creation of a real option as an entrepreneurial process, which transforms inventive ideas into profitable innovation. This constitutes a step toward an option based-theory of the firm by describing the emergence of a firm's options and the strategic building of new competences for exercising these options. In addition, this approach offers a parallel understanding of why the real option theory is less used in practice than in theory.
\end{abstract}

Key words: Real Option, Theory of the Firm, Entrepreneurship, Dynamic Capabilities JEL-Classsification: L29, D83, M13, M19.

\footnotetext{
* BETA, University Louis Pasteur, 61 Avenue de la Foret Noire, 67085 Strasbourg, France, email : burger@cournot.u-strasbg.fr
} 


\section{Justifying the Origin of Real Options and their Difficult Evaluation in Strategic Management}

The success of a firm depends on her capability to create and exploit new projects. Projects are competitive opportunities that the firms must recognize, evaluate, and on which she has to be able to apply operating capabilities to take advantage of them. The general management responsible for the firm's strategic direction fails frequently to manage the organization's technological innovation process that creates these opportunities (Hayes et al. (2005)).

To help managers in their decision-making process in uncertain environments new techniques and theories are developed, one of them is the real option theory. This conceptual decision-making framework is about to become a standard. The formal approach, originating from financial models, introducing future uncertainty and the opportunities a firm can seize is appealing for managers. However the use of this approach raises many questions linked to the theory of the firm and strategic management (Grundy (2004); Warner et al. (2006)).

A major issue, almost ignored in this literature, is the question of the origin of the real option. In this work we try to explain the origin of the option and provide some elements for a better evaluation of the option in theory and practice. We use the entrepreneur as the resource recognizing and creating options. The lack of consideration devoted to entrepreneurship by most real option research works ${ }^{1}$ explains why real option theory focuses mainly -if not exclusively- on the valuation of existing options and not on their creation. The insights gained from considering real option and entrepreneurship are bi-directional. On the one hand entrepreneurship, in a resource based framework, can explain the origin of real option and contribute to a better evaluation of its value. On the other hand real option can explain the direction a decision maker gives to the development of the new capabilities and resources, as an entrepreneurial activity, by suggesting another use of the resources. Combining entrepreneurship and real option explains the heterogeneity of the firm and its resources collection and capabilities building.

1. For a notable exception see McGrath (1999). 
In the following work, we first give a brief presentation of what real options are and we highlight the important elements and variables that create and influence their values. In a part point we develop the notion of real option in the specific field of strategic management. This leads us to consider the successive developments and criticisms of an option chain. In this part we introduce the distinctive roles of entrepreneurs and managers in order to obtain a richer representation of the real option. In a third part we analyse the components of the option values in the light of the new notions introduced and in conclusion we discuss the difficulties to implement all this determinants in practice.

\section{Requisites for an Option-Based Approach of the Firm}

In the strategic theory of the firm the most obvious of the long-term goals is the survival of the firm. Survival is achieved by seizing profitable opportunities when these opportunities arise or are encouraged to arise. In the long run the profitability, survival and growth of a firm do not depend so much on the general efficiency with which it is able to organize the production as it does on the ability of the firm to establish one or more wide and relatively impregnable competence 'bases' from which it can adapt and extend its operations in an uncertain, changing, and competitive world (Teece et al. (1997)). In this approach the value of a firm is directly linked to the resources of the firm. These resources are tied together in a firm specific way, giving a firm the capability of achieving some tasks better than others. The heterogeneity in resources is a main reason why firms exhibit different profits and survival rates (Barney (1991)). As human resources are the repository of productive knowledge (including tacit and explicit knowledge) their development highly influences the modification of productive capabilities. Creating new knowledge, the most important task of the firm, enables the firm to produce new goods, create a new organization, or upgrade her efficiency. The learning mechanisms are at the origin of these capabilities and allow firm to grasp new opportunities (Prahalad and Hamel (1990). Making good use of an opportunity that brings value to the firm is nowadays called the real option, so holding and being able to exercise this real option depend fundamentally on the competences and learning activity of the firm. 
An option gives the right but not the obligation to take a specific decision (invest, defer, alter) on an underlying asset, for a predetermined price at, or before, a certain time. For example, a firm can possess a production plant, and choose, depending on customer demand or competition, to construct a bigger capacity plant to obtain economies of scale (a growth option) or, on the contrary, to momentary shut down the plant (option defer production). The firm has the right, but not the obligation, to change her production capacity. This option, depending on the information at hand at the moment of exercise, allows the firm to catch new revenues flows or to reduce costs.

The conceptual analogy between real and financial option is shown in Table 1.

Insert Table 1 about here

In this table are listed the five fundamental variables that enter in the option calculation. Two of these variables, that we use extensively in the third part of this work are $(\mathrm{K})$ and (S). The exercise price $(\mathrm{K})$ represents the amount the firm must pay when the option is exercised. For instance, if the firm wishes to construct a new plant, $(\mathrm{K})$ would represent the construction costs. (S) represents the value of the constructed plant and corresponds to the present value of the future cash flows that the firm earns by exploiting the plant. Based on these variables we can calculate the cost of acquiring the real option. We distinguish between this cost (also known as premium) at the origin of the option and the value the option gets when the firm holds it a certain time. This value is important for calculating the optimal moment of exercise of the option. Once the option is exercised, the firm looses the value of the option for obtaining the underlying asset of the option (S) minus the cost of investment (K). It may happen that the value of the option is higher than the gain expected from the exercise of the option. This excess of value derives from the presence of uncertainty that exists between the date of evaluation and the expiration date of the option. The longer the time to exercise, the higher the difference between the good and bad situation outcomes that the option allows to seize as higher the option value.

This property comes from the interplay of three conditions that shape the value of the option: uncertainty, flexibility and irreversibility. 


\subsection{Uncertainty}

Real option shares with financial option their main reason of existence: uncertainty. In the financial case, uncertainty is reduced to risk in the form of probabilities of appearance of good or bad outcomes. These probabilities are estimated, e.g. for a stock price, by the historical data of stock price. These probabilities are exogenous for the firm and are not influenced by her behaviour. In the case of real option uncertainty can take a much broader variety of forms, uncertainty about the demand for a good, uncertainty in the reaction of rival firms, uncertainty of the outcomes of a court decision... We see in the discussion in the second part of the present work, that uncertainty for real option can be made endogenous.

\subsection{Flexibility}

The second condition of existence of the real option is flexibility. Flexibility represents the possibility for an investor to exercise a real option (invest in a project, etc...) or to abandon it. It is flexibility that gives an option its asymmetric payoff. This flexibility adds a positive value to the project. In the case of a financial project, flexibility is identified as the possibility of transferring rights onto an underlying asset, as counterpart for a payment. In the case of a real option this flexibility has a variety of expressions. We can define six broad categories of real options, which correspond to six expressions of the flexibility as shown in Table 2.

Insert Table 2 about here

\subsection{Irreversibility}

The last condition of existence for a real option is the irreversibility of the investment. A decision can be considered irreversible if it significantly reduces for a long time the variety of choices that would be possible in the future. In case of financial option, irreversibility is materialized by the payment of the premium. This premium, whatever the buyer decides, is definitely acquired by the seller. But the option can be sold again on the financial market, this makes the characteristics of irreversibility for a financial option relatively unconstraining.

In the real option case the irreversibility is of capital importance. To sell the project again, or the rights of a project is only possible in the case of patents. The irreversibility is not only manifested in the financial part as a forgone financing capacity that limits the 
investment possibilities of the firm, but also in terms of capabilities and knowledge accumulated that locks the firm in some specific activities.

\section{The Option Chain}

The existence and development of the real options need, as we have seen, the fulfilment of some conditions (uncertainty, flexibility, irreversibility). These conditions, sufficient in a financial approach, are only necessary in a managerial approach where the origin of the option, conditional to behaviour of individuals, needs to be explained. Who creates the real option?

To answer this question we will analyse the different contributions made to the real option theory by the strategic management approach. The development we propose is related to the understanding of the label real option. Too often, the adjective "real" is explained by making exclusive reference to the financial theory arguing that financial options refer to a financial traded underlying asset. By contrast the real option refers to a non financial (real world) asset, e.g. a production facility or an R\&D patent. This definition is true according to the origin of famous option calculation formulas but incomplete in terms of the problematic underlying non-financial assets. Carr (2002) and Kogut and Kulatilaka (2004) pinpointed that many firms, even aware of the existence of an opportunity of profit, do not possess the option to exploit the opportunity or cannot exercise the option correctly. This limitation arises, among others, from the lack of knowledge and competences needed to exploit the opportunity. Knowing that an opportunity exists and being able to exploit that opportunity are different things. For us a real option is an option that the firm is aware of and for the exploitation of which she has constructed the necessary resources and knowledge. So a real option is an option that the firm can really exercise.

Figure 1 represents the successive developments of the real option chain in the strategic management literature. The following discussion and presentation of the option chain and the introduction of the entrepreneur / manager rely on that figure.

Insert Figure 1 about here 


\subsection{Standard option exploitation}

The area labelled (1) represents the initial step of the real option theory as it can be found in today's major textbooks on that topic (Trigeorgis (1996)). This literature focuses mainly on the calculation of the value of the real option and the determination of the optimal timing for exercising this option.

This short option chain is the following. The option is supposed to exist, to lay at the hand of the decision maker. The decision maker (always referred to as the manager in this literature) evaluates the option contingently to the future possible states, and decides to exercise it or not. The value thresholds determining the decision obtained are in general different from those determined by standard net present value techniques. For example, in the presence of a option to wait, this hurdle is much higher. An opposite example would be the growth option, which justifies investing in projects that have as stand alone a negative present value. Only future development possibilities can justify the investment.

When this hurdle is hit or exceeded the option is exercised, which means that the project enters, for instance a phase of building and exploitation. Once the firm enters the market new options can arise such as expanding the size of the plant, diversifying the production, or in the worst case, stopping the production and shutting down the factory.

\subsection{Exploration of the identification of opportunities, the emergence of the shadow option}

This development, as noticed by academics in the strategic management field, makes the important assumption that the option exists and that the decision maker is informed of its existence. This is, obviously, not always the case. Bowman and Hurry (1993), struck by that implicit hypothesis, introduced the notion of shadow option, the option that a firm could exploit, or at least consider in her portfolio of choices if she was aware of it. This approach is appealing for the introduction of information systems in the firm, the use of consultants and technological watch agencies. The option that a firm possesses depending on resource and knowledge available inside the firm but that the decision maker ignores.

Opportunities (and not yet options) come into existence when individuals have different beliefs in the possibilities offered by the available or potential resources to transform some inputs into some outputs that can be sold and raise a profit. An opportunity is a 
favourable, momentary circumstance or situation that has been recognized after one has sought for it or has spontaneously appeared. Schumpeter (1934) distinguished between the notions of invention and of innovation; we draw a parallel between these notions and the notion of option. An invention is the discovery of an opportunity, what Bowman and Hurry described as a shadow option. An innovation is a transformed invention, originated in an opportunity, into an exploitable and hopefully profitable option. When the opportunity becomes exploitable the firm possesses a real option. The transformation of the invention into a profitable innovation depends on whether the firm has the appropriate resources at the right moment.

Once the shadow option is taken into account (area (2) Figure 1) the rest of the option chain can be considered in the same way as described above. When the shadow option is recognized, it moves from shadow option label to real option. The option has then to be evaluated, compared to the other options, and also take account of probable interactions between them in the portfolio of option decisions of the firm.

The addition made by Bowman and Hurry does not completely answer the question of the origin of the real option, it merely shifts the debate. Instead of explaining the origin of the real option, the genesis of the shadow option must be elucidated.

\subsection{Strategic management debates}

Before introducing the entrepreneur / manager we add to Figure 1 the outcomes of a recent debate in the strategic management literature about real option that highlights other problems in that option chain. This debate focuses on the link between the different steps of the option chain, we refer to them by the letters $\mathrm{A}, \mathrm{B}$, and $\mathrm{C}$. These three cases are explored below.

The debate starts at A, based on works by Adner and Levinthal (2004). They observe the growing interest in real option while noticing that the terminology of real option is very trendy but encompasses different realities, including works which talk about real option when they should not. In their work these authors describe what is not a real option, and show the characteristics of a real option. They show that a real option is not something that the firm possesses for free, but only in paying a premium (but the payment can be not deliberate). This characteristic acts at the determination of the real option, so it is natural to place this debate between the shadow and the real option. 
Kogut and Kulatilaka discuss the difficulties of translating concepts from one domain into another. In this case, from the financial world to strategic management. This translation can be particularly misleading if one does not take into account the specificities of each domain and performs too radical translation. They also consider the qualification and applicability of the option logic according the ability that a firm has to influence the option. This is a fundamental difference from the financial option, where the firm's action does not change the value of the underlying asset traded on financial markets.

The mark B on Figure 1 refers to two organizational forces which act to undermine the real option approach in strategic decision making.

(i)-The fundamental distinction between an option and a standard evaluation technique comes from the non-symmetric payoffs of the option. The models of real option define the investment only if positive outcomes emerge (the good state of the world), avoid negative outcomes by stopping investment in bad states of the world. Stopping investment is a key to limiting downside risk. Adner and Levinthal (2004) highlight the importance of abandonment when maintaining options alive requires active investment and involvement in individuals and capital to maintain the capabilities of the firm and to exploit the option if it becomes profitable. They notice that the firm can change her capabilities (with time and money), she can also theoretically change the condition of use of the option, and so manipulate the outcome of that option. In that case, an option can be made profitable. If the firm decides to act this way, the involvement of the firm may be costly and lead to bankruptcy, because the firm is always a step closer to making the option interesting to exercise, without reaching this exercise point. This means that the firm needs to have a clear agenda of action to undertake and follow it when time has come to abandon an option definitively. If this abandonment schedule is not followed the firm avoids the downside risk of the real option but suffers a large downside risk of the shadow option.

(ii)-These authors also notice that the value of the option comes from the uncertainty of the outcome. Thus, the higher the uncertainty, the broader the set of possible outcomes. On the contrary when the uncertainty is not resolved another trap for decision makers appears. If uncertainty is stable or increases, the variety of choices of the firm increases. 
Exploring this broader space of uncertainty has an impact. The exploration of this variety increases the possibilities of choice, creating "options on options", instead of reducing uncertainty. Thus, the more the firms invest in her real option portfolio, the more the size (number of options) and value of the portfolio increase, but the less the firm is able to exercise a significant part of her option. In that case the firm never comes to exercise because the more she searches, the more the option value, and the potential value of her investment if exercised increase.

This leads to some kind of hysteria, where the firm increases her capabilities without building the capacities for production and lacks the possibility to enter the exploitation phases (Kogut and Kulatilaka (2001)).

The mark C on Figure 1 refers to the exploitation of the real option an the conception of further development phases.

Kogut and Kulatilaka give a numerical example of status quo biases. They discuss the fact that new options, will bring a change in the organizational structure of the firm. And the individuals will see their positions in the organization chart modified. They can be reluctant to accept these modifications and slow down the appropriate schedule of application. Numerical simulation shows that missing the optimal timing will significantly decrease the value of the option, and so eliminate the potential gains coming from its introduction.

McGrath (1999) provides an analysis of the bias that can affect decisions at this stage. In particular if one or several of the previous steps have not been a complete success. Some of the biases modify the smoothness of the option chain during the different steps. These errors and biases can leave marks on the firm and the decision-makers.

At the end of the represented option chain, the firm can enter another chain, depending on the resources available. The biases can lead to overreaction and seriously alter the value of the future shadow and real option. In the case of success in the production phase, the firm has a strong incentive to explore the future in the same way acted before. This can be a poor guide for action since the routines that proved effective in exploitation are probably not the most appropriate for the creation of new opportunities. They make an imitation of creativity and are without any surprise.

Moreover, because the routine is a success, it is difficult for a management to abandon it. Resting too long on existing routines reduces the dynamic capabilities of the firm and 
her ability to build new resources and obtain rents. Moreover, because the routine is a success, it is difficult for a management to abandon it. Resting too long on existing routines reduces the dynamic capabilities of the firm and her ability to build new resources and obtain rents.

In Table 2 we list some real option categories. Many of them are dependent of market conditions. If market conditions are more favourable than expected the firm can expand the scale of production or accelerate resource utilisation. Conversely if conditions are less favourable than expected, the scale of operation can be reduced. The adaptation of the production to the quantity of product demanded is part of the option logic. This logic contains also the option to adapt the production gradually to the market condition, including qualitative adaptation, skills and routines adaptation through staged option. The speed of executing routines, of changing their contents and of switching between them is analysed by Cohen (1991). For this author the foundation of dynamic capabilities are the skills and routines of the individual members. The building, modifying and refinement of that repertoire of routines constitute much of the performance that can be found in learning curve research. If a firm, for market reasons or manager entrenchment reasons, decides not to change the production, the ability of the firm to adapt or change her routines will vanish and so will her dynamic capabilities and option creation capacities. The stability of the environment, the stickiness of habits, is unfavourable to the development of the needed entrepreneurial spirit. Hoverer this debate does not alter her short term profitability which can be strongly increases by resting on exiting routines.

Many psychological phenomena, or cognitive biases can alter the development of future options, for example the confirmation bias. During the decision phase, individuals may see information with negative connotations as less plausible, on the other hand promptly take into account information with positive connotations. This leads the numerical part of the evaluation to be false (costs, revenues, opportunities, profits). Another bias is the overconfidence bias, when individuals attribute success to one's own actions and failure to bad luck (Barney (1986)). Let us take the example of a "technology guru", whose advise influences the market. If firms, or investors, follow his advice, they invest massively in an option that has probably no value. Entrants see new markets as profitable, full of growth option and so enter the market. If other firms make the same observation their mutual entrances lead to a reduction of the profit. 
The mirror effect of this bias is to assimilate everything that leaded once to a failure to a negative path that must not be followed again. This eliminate all attempts to build similar new shadow options in the future.

All those biases do not mean that one should reconsider the advantage of using real option in comparison to other techniques. The option represents the flexibility inherent to the project. Using techniques without representation of the flexibility clearly misleads the judgement of the decision makers, and following our discussion, does not imply that the managers take a better timing, relying on one or the other technique. Why should decisions following the prescription of simpler techniques not been marred by errors?

The reminding important point on the origin of the shadow option, our addition to this chain, is represented in the area 3 on Figure 1.

\section{Introduction of the entrepreneurial resource}

A historical approach of entrepreneurs in the microeconomic theory shows that when authors need to introduce novelties or special variations into a theory of the firm they often refer to the figure of the entrepreneur (Barreto (1989)). In this work we consider entrepreneurship as a resource of the firm and an opportunity exploiter (Cohendet et al. (2000)). The characteristics given to entrepreneurs are widely influenced in economics by the work of Schumpeter and Kirzner (1979). Kirzner introduced the concept of "entrepreneurial alertness" as the special ability of the entrepreneur to see where products (or services) do not exist and can be profitably exploited. Alertness exists when one individual has an insight into the value of a given resource while others do not. From this perspective, entrepreneurial alertness refers to "flashes of superior insight" that enable one to recognize an opportunity when it presents itself.

As mentioned the starting point of the shadow option is the identification of an opportunity. This identification is often a vision resulting from the imagination of the entrepreneur of what could be an opportunity. This imagination, as described by Witt (1998), leads to action. The identification of a shadow option consists of the entrepreneur's representation of the world. The entrepreneur acts in accordance with his/her newly created state of the world. As a consequence, the entrepreneurial resource 
will begin to dispatch information about his/her findings. After that discovery begins the search for resources and the creation of knowledge for transforming this shadow option into a real option. The search process that follows is widely influenced by the vision of the entrepreneurial resource.

\subsection{Entrepreneurs, options and heuristics}

The entrepreneur's representation of the world and behaviour for searching how to move from the shadow to a real option is a special kind of heuristics. Kogut and Kulatilaka (2001) give an insightful approach of real option, capabilities and heuristics. The authors split heuristics into two parts, a cognitive frame and rules of search. A cognitive (or heuristic) frame refers to the representation of the problem and the expected solution space. The heuristic rules of search are the algorithms by which solutions are found in the represented solution space. These authors identify four qualities of a good heuristics: it is easy to use, easy to communicate, it provides a better direction than the ones currently employed, and it motivates people who have to implement the strategy. The well-known matrix for portfolio analysis of the Boston Consulting Group is a perfect example of a heuristics. The vision span in this matrix is a child's play, the pictures of cow, dog, star and question mark are understood and remembered by everybody, from a first year management student to the executive (Macmillan and Tampoe (2001)). The BCG matrix example is only one part of a heuristics, it represents the cognitive frame. Nelson and Winter (1982) used the notion of routines, which is organizational enactment of heuristic problem solving for representing the second part of a heuristics, the rules of search.

The definition of vision and imagination that we developed previously implies a special cognitive frame. For Busenitz and Barney (1997) entrepreneurs use heuristics more extensively than managers in larger organizations. In using heuristics they make simplifications that allow the development of ideas, enable them to continue without answering all possible problems that may arise. Especially in complex situations where less complete or uncertain information is available such behaviours ease the evolution of the organization. The differences in the use of heuristics between entrepreneurial and managerial firms reside in the fact that entrepreneurial ones are more responsive to opportunities. The differences in their appraisal of the future suggest a difference in the option identification. Also the heuristic-based logic enables entrepreneurs to make sense 
of uncertain and complex situations more quickly than hierarchic management. Gavetti and Levinthal (2000) pinpoint that decision making in such a context is forward looking, as opposed to backward looking procedures that develop no options but focus on resources already in use.

\subsection{Combining resources, the emergence of the real option}

Once the opportunity is identified one can notice that the entrepreneur certainly does not have the specific knowledge and expertise in all domains necessary to fulfil his goal. This lets him in charge of finding and combining the adequate resources for his endeavour. The acquisition of a new productive capability by building a new competence is not instantaneous. The building process is mainly path dependent and involves tacit knowledge acquired by learning by doing and experimentation. This implies that firms who create knowledge are also option-creating firms. By creating new knowledge these firms expand their cognitive frames, part of the real option heuristics. The value of the entrepreneurial resource appears here as having the ability to combine different expert knowledge in way to exploit opportunities. The individual we call entrepreneur is not necessarily outside of the firm, he is more likely a member of the firm becoming a intrapreneur. Neither is there a necessity that this is done by a sole individual, a group of individual, termed diffused entrepreneurship could perform this action. As the diffusion of the entrepreneur mind becomes broader, we move from a Schumpeter Mark I to a Schumpeter Mark II framework.

\subsection{Creation of new capabilities and productive knowledge}

Once the entrepreneurial resource obtains commitment for searching resources and creating new knowledge the shaping of the real option begins. The search for appropriate resources can be carried out inside or outside the firm. An intuitive solution for the search for new resources is to rely on communities. Communities, according to the knowledge-based theory of the firm, are the intangible places where knowledge is shared and created. Each community has its own specificities, concerning the modes of learning, the type of knowledge created, autonomy, and hierarchical architecture. The organizational and knowledge environment of communities has thus important consequences for our understanding of how co-ordination, motivation and sharing of visions work, and how they structure the firm's enabling options. The nature of the activities concerned (production, research development, finance, etc.), the goals and 
motivations of the potential users and developers of the innovative idea contribute to the speed, the inflexibilities, and the different dimensions of the emerging routines used to give consistency to the emerging real option. Two major types of communities are usually presented in the literature, communities of practice and epistemic communities. The key point to distinguish them is that epistemic communities are truly oriented toward new knowledge creation, whereas communities of practice are oriented toward the achievement of the activity (Cohendet and Llerena (2003)).

Creating the underlying knowledge necessary to transform a shadow option into a real option is a task corresponding to the attributes of an epistemic community. Using the real option and enhancing the practical implementation of a productive process are tasks corresponding to a community of practice. Thus, the passage from a shadow to a real option corresponds to the transformation of the epistemic community into a community of practice. The type of management has also to change from an entrepreneur to a manager. Nooteboom (2000), building on a different representation of exploitation and exploration, than the shadow and real option concept we use, comes to the same utilisation timing between entrepreneur and manager.

The point of view we take in the major part of this work is that a firm must invest in knowledge assets. Unlike physical or financial assets, knowledge can be transferred throughout the firm and applied to various projects and processes. That is the essence of a core competence as the basis for strategy. The options logic seems particularly compelling for evaluating such knowledge assets. If a knowledge asset created by an option combines with existing knowledge, the firm may be more likely to exercise the option than if the asset were isolated. This is because the value of the knowledge is contingent on its transfer, combination and recombination with other knowledge-based assets in a firm.

Another point of view would be that, when establishing an option on knowledge assets, the firm may have the choice of combining new assets initially or keeping them isolated. In some cases, an incompatible culture, routine, or technology must be kept isolated from other assets in order to thrive. Isolation also serves to limit the development of social networks that may lead to the escalation of commitment (Andrikopoulos (2005); Coff and Laverty (2001)). The importance of knowledge asset 
in the strategic approach of real options is unquestionable. Nonetheless the influence of the individuals responsible for the management of this specific asset is not to be overlooked. These individuals include the entrepreneur and manager whose roles have been discussed previously, but also the communities.

\subsection{From entrepreneur to manager}

A recurrent if not fundamental problem in real option valuation is the definition of the value of the option. The determination of the value of the option is a critical aspect because it determines whether the option is used or not, and if it is when it is appropriate to use it. Troubles arise when trying to identify numbers for the different variables used in real option formulas, as Luehrman (1998) suggests, practitioners often have to "take an educated guess".

The decision to exercise the option and to turn to a production phase correspond to a managerial decision making process. A reason why the manager does not enter the option chain earlier comes from the nature of the output of the shadow option. The output of the knowledge building process (what is done during the shadow option) is difficult to evaluate, the knowledge is disperse and the manager is not aware of all pieces before the entrepreneur ends his action. The managerial decision depends on the balance between entering the market with the actual resources and knowledge or waiting for absorbing more capacities. As shown by Lane et al. (1998) managerial capabilities are developed by training, repetition in decision-making, rules of thumb implementation and day-to-day management. This approach of managerial decision is in fact the situation mostly described by real option valuation problems (area 1 Figure 1), where basic managerial economic inputs such as cost or existing demand (including some standard deviation) are used. This data are made by entrepreneurial action for convincing of the accuracy of their first vision. If manager take this data into account the entrepreneurial part of the option chain is a success. At this point we catch up with existing literature of real option concerned with evaluation based on some informative inputs. This leads us to give a description of value determination of the option based on theories of the firm considerations. 


\section{Evaluation along the Option Chain}

In the following we present an original approach for assessing the value of the real option based on the difference between shadow and real option. We do not pretend to give a unique and exact value, rather an interval where the "real" real option value should be.

We determine boundaries for four variables that intervene in the real option analysis, namely: the premium that is endured to acquire the option, the striking price for exercising the option, the gain if the option is exercised and the value of the option. Two parameters usually found in real option are omitted, the interest rate (assumed constant) and the time to expiration. The variables are discussed for both types of option, shadow and real. Of course it is difficult to assign costs directly to an inventive activity as needed by the formulas in particular for the shadow option. Also these costs can be incurred by the firm without obtaining an option. On the contrary the costs supported by the firm can serve to generate more than one shadow option. These costs can be taken in two different ways. If the firm deliberately tries to create a favourable environment for inventive ideas the costs are accountable and justifiable. If the firm does not support these costs deliberately the occurrence of the shadow option is just a non-intended event that the inefficient organisation produces by chance. The following discussion is summarised in Table 3.

Insert Table 3 about here

\subsection{The shadow option}

- The premium of the shadow option includes the cost supported by the firm for being aware of the existence of an opportunity. At the individual level it includes the cost of the entrepreneurial resources which launch the process expressed in wages and training cost of the employee without a direct link to the actual production. At the organization level it necessitates some weak ties between the task of an individual and his productive behaviour. The creation of an option should here be linked to organizational slack. For March (1979) organizational slacks are the spare resources and unexploited opportunities that act as a buffer against bad times. These unexploited opportunities and spare resources come from the fact that the firm does 
not always optimise. The slack smoothes the performances of the firm, reducing performance during good times and improving it during bad times. Organizational slack costs are the costs of the resources that a firm acquires and that are not committed to a direct use or/and necessary expenditure (see Bourgeois (1981) for an interesting discussion of how to measure slack). Of course the kind of inventive idea arising from an employee such as a manager or a product line agent creates a different type of option at different costs, e.g. product innovation, process innovation...

- The exercise price of the shadow option includes the costs that are necessary to transform the shadow option into a real option. They are costs of negotiation (in time) that the entrepreneur spends explaining the idea and convincing the decision makers in the firm to spend financial resources on the competence building process. If the firm decides to build the competences (after eventually some market analysis costs) the costs come from the activity of search and combination of different types of resources in such a way as to produce new knowledge needed to practically implement the inventive idea. Good proxies for such costs are $R \& D$ expenses or start-up creation outlays (in the sense that start-ups are legally different entities created to try to transform an idea into something profitable).

- If the shadow option is exercised the gain depends on the best use of the new combination of resources the firm has realised. The best use determines the highest gain the firm can obtain by combining resources, through internal use of the resources or by selling them on a market. The combination can have a value of zero if no productive use following the investment can occur, or on the contrary the uniqueness of the combination can be highly valuable if the opportunity it contributes to seize is considerable.

- The value of the shadow option is generally divided in two parts, the intrinsic value and the speculative value. In the case of a shadow option the value is at least the gain of selling the resources built on the market price (which can be zero) and a maximum value incorporating all future strategic options that can be built on the basis of these resources. In this analysis the boundaries of the shadow option are zero and infinite. This approximation is of course not of great help for someone who 
tries to identify the exact value of the firm's option. But we have to notice that this value is in constant variation. So this framework shows clearly that real options are only useful as a tool if decision makers agree to monitor them often and to specify boundaries of acceptance in advance (e.g. rules of thumb) and to stick to these boundaries. Also the value of the shadow option is mainly influenced by its speculative value. Many over-optimistic analyses that are performed confuse the value of the shadow option with the value of the real option they try to evaluate. For us the value of the shadow option is only a transition point to guide an effective real option evaluation.

\subsection{The real option}

- The premium of the real option depends on the previous initiatives of the firm, whether the firm has already invested in the shadow option or not. If the state of the firm follows the exercise of the shadow option then the sum of the exercise price and the premium of the shadow option forms the premium of the real option. If the firm has not previously invested in the shadow option the costs are at least equivalent to the gain of the shadow option. This mean that the firms who want a certain bundle of competences have the choice between building these resources within the firm, which can be extremely time consuming, or buying them on the market which can be expensive. The interest of many firms for a rare resource increases the price on the market. Langlois (1992) gave an example of cost that influences the ranking of activities (and competences) a firm can acquire. If the shadow option costs are supported, the ranking of the profitable activities a firm can expect to enter into is different from the ranking of a firm that has not incurred these costs.

- The cost of exercising the real option. Now that the firm is assumed to possess the necessary competences to exploit an opportunity, e.g. to enter the productive stage, she has to hire employees, build a productive plant etc...The firm can also switch employees from an existing production plant to another, abandoning an older product for launching a new one (as depicted in the BCG matrix). These costs are usually the only ones taken into account in standard real option evaluation. 
- The remaining two points, gain when the option is exercised and value of the real option, are consistent with the definition widely found in corporate finance books. The gain obtained when the real option is exercised is the present value of the cash flow generated by the option and the value of the real option is given by adequate formulas depending on the market structure, the demand of the consumer's variation...

\section{Discussion}

The aim of this article was to show the translation of the option concept from the financial to the strategic management field. We see that, in addition to the financial characteristics needed to obtain an option value, the management perspective needs to specify the roles of individuals. We use the concept introduced by Bowman/ Hurry (1993) of shadow option and option chain in our presentation that we enhance with entrepreneurship. We suggest that entrepreneurship in a new firm, or an existing one, is at the origin of real option.

As we have shown a firm with an entrepreneurial heuristics will give a different value to resources and to options than other firms (see Table 3 for some examples). The value of the competence is a capital part of the real option value, and conversely future option determines partly the competence value.

In theoretical approaches, real option shows a greater effectiveness than standard evaluation techniques. However, one can be puzzled to see how few firms use real option. This can be explained by several facts, first the mathematical background needed to use option techniques can be too demanding. Secondly, in addition to the biases listed in this paper, a manager can encounter problems to represent option cognitively. Miller and Shapira (2004) explore this point with a study on option evaluation on a sample of finance trained students and practitioners. They notice that the options are systematically misevaluated, especially because people take into account facts that have in reality no impact on the option value. Howell and Jägle (1997) in a study over five different industries note that the values attributed to options are systemically over or under evaluated depending on the industrial sector of the interviewed manager. 
We proposed in that work an explication of the difficulty to use the real option theory in practice. Not only are the whole costs that should be taken into account in option evaluation difficult -if not impossible- to account for (the cost of shadow and real option), but also the creation and utilisation of this option needs the intervention of different individuals (entrepreneurs and managers) who have different points of view and different value representations. This can lead a firm, not to consider options that might result in a profitable exploitation of an opportunity.

Future developments of real option should increase the integration in the real option theory with behavioural finance and the theory of the firm considerations. This would be a way to obtain a strategic theory of the firm explaining the difficult tasks of capabilities building and capacities exploitation.

\section{References}

Adner, Ron and Daniel A Levinthal (2004a), What is not real option: identifying boundaries for the application of real options to business strategy, Academy of Management Review 29, 1, 74-85.

Adner, Ron and Daniel A. Levinthal (2004b), Real options and real tradeoffs, Academy of Management Review 29, 1,120-126.

Andrikopoulos, Andreas (2005), The real-options approach to intellectual capital analysis: a critique, Knowledge and Process Management 12, 3, 217-224.

Barney, Jay B. (1986), Strategic factor markets: expectations, luck, and business strategy, Management Science 32, 1231-1241.

Barney, Jay B. (1991), Firm resources and sustained competitive advantage, Journal of Management 17, 1, 99-120.

Barreto, Humberto (1989), The Entrepreneur in Microeconomic Theory: Disappearance and Explanation, Routledge.

Bourgeois, L. J. III. (1981), On the measurement of organizational slack, Academy of Management Review 6, 1, 29-39. 
Bowman, Edward H. and Dileep Hurry, D. (1993), Strategy through the option lens: an integrated view of resource investments and incremental choice process, Academy of Management Review 18, 4, 760-782.

Busenitz, Lowell W. and Jay B. Barney (1997), Differences between entrepreneurs and managers in large organizations: biases and heuristics in strategic decision-making, Journal of Business Venturing 12, 9-30.

Carr, Nicholas G. (2002), Unreal Options, Harvard Business Review 80,12, 22.

Cohen, Michael D. (1991), Individual learning and organizational routines: emerging connections, Organization Science 2, 135-139.

Cohendet, Patrick and Patrick Llerena (2003), Routines and incentives: the role of communities in the firm, Industrial and Corporate Change 12, 2, 271-297.

Cohendet, Patrick, Llerena, Patrick and Luigi Marengo (2000), Is there a pilot in the evolutionary theory of the Firm?. In N. Foss and V. Mahnke (Eds.) Competence, Governance and Entrepreneurship. Oxford University Press, 95-115.

Coff, Russell W. and Kevin J. Laverty (2001), Real options on knowledge assets: panacea or Pandora's box?, Business Horizons 44, 73-79.

Foss, Nicolai J. (1997), Resources, Firms and Strategies: A Reader in the Resourcebased Perspective, Oxford University Press.

Gavetti, Giovanni, and Daniel A. Levinthal (2000), Looking forward and looking backward: cognitive and experimental search, Administrative Science Quarterly 45, 1, 113-137.

Grundy, Tony (2004), Rejuvenating strategic management : the strategic option grid, Strategic Change 13, 111-123. 
Hayes, Robert, Pisano, Gary, Upton, Davide and Steven Wheelwright (2005), Pursuing the Competitive Edge, New York: Wiley.

Howell Sydney D. and Axel J. Jägle (1997), Laboratory Evidence on how managers intuitively value real growth options, Journal of Business Finance \& Accounting 24, 915-935.

Kirzner, Isreal (1979), Perception, Opportunity and Profit. Chicago: University of Chicago Press.

Kogut, Bruce and Nalin Kulatilaka (2001), Capabilities as real options, Organization Science 12, 6, 744-759.

Kogut, Bruce and Nalin Kulatilaka (2004), Real options pricing and organizations: The contingent risks of extended theoretical domains, Academy of Management Review 29, $1,102-110$.

Langlois, Richard N. (1992), Transaction-cost economics in real time, Industrial and Corporate Change 1, 99-127.

Leiblein, Michael J. (2003), The Choice of organizational governance form and performance: predictions from transaction cost, resource-based, and real options theories, Journal of Management 29, 6, 937-961.

Luehrman, Timothy A. (1998), Investment opportunities as real options: getting started on the numbers, Harvard Business Review July-August, 76, 4, 51-61.

Macmillan, Hugh and Mahem Tampoe (2000), Strategic Management, Oxford University Press.

March, James G. (1979), Stanford Business School Alumni Association. Stanford G.S.B., interview with James G. March, 47, 3, 16-19. 
McGrath, Rita G. (1999), Falling forward: real options reasoning and entrepreneurial failure, Academy of Management Review 24, 1, 13-30.

Miller Kent D. and Zur Shapira (2004), An Empirical test of heuristics and Biases affecting real option valuation, Strategic Management Journal 25, 2004, pp.269-284.

Nelson, Richard R. and Sydney G. Winter (1982), An Evolutionary Theory of Economic Change, Cambridge: Harvard University Press.

Nooteboom, Bart (2000), Learning and Innovation in Organizations and Economies, Oxford University Press.

Prahalad, C. K. and Gary Hamel (1990), The core competence of corporation, Harvard Business Review 68, 3, 79-91.

Schumpeter, Joseph A. (1934), The Theory of Economic Development, Cambridge: Harvard University Press.

Teece, David J., Pisano, Gary and Amy Shuen (1997), Dynamic capabilities and strategic management, Strategic Management Journal 18, 7, 509-533.

Trigeorgis, Lenos (1996), Real Options: Managerial Flexibility and Strategy in Resource Allocation. MIT Press.

Warner, Alfred G., Fairbank, James F. and H. Kevin Steensma, (2006), Managing uncertainty in a formal standards-based industry: a real options perspective on acquisition timing, Journal of Management 32, 2, 279-298.

Witt, Ulrich (1998), Imagination and leadership : the neglected dimension of an evolutionary theory of the firm, Journal of Economic Behavior \& Organization, 35, 2, 161-177. 
Table 1. Correspondence between financial and real options

\begin{tabular}{|l|l|l|}
\hline Variable & Financial Option & Real Option - Project \\
\hline $\mathrm{K}$ & Exercise Price & Cost to acquire the asset \\
\hline $\mathrm{S}$ & Stock Price & $\begin{array}{l}\text { Present value of the future cash flows } \\
\text { from the asset }\end{array}$ \\
\hline $\mathrm{T}$ & Time to expiration & Length of time the option is viable \\
\hline$\sigma^{2}$ & Variance of the stock returns & $\begin{array}{l}\text { Riskiness of the asset, variance of the } \\
\text { best and worst case scenario }\end{array}$ \\
\hline$r$ & Risk-free rate of return & Risk-free rate of return \\
\hline
\end{tabular}

Table 2. Variety of real option and corresponding flexibility

\begin{tabular}{|l|l|}
\hline Type of real option & Expression of the flexibility \\
\hline The option to defer & $\begin{array}{l}\text { The option to defer, or to wait, derives its value form } \\
\text { reducing uncertainty granted by the ability to wait until } \\
\text { more information has arrived }\end{array}$ \\
\hline The option to abandon & The possibility to shut down an unprofitable project \\
\hline The option to switch & $\begin{array}{l}\text { The flexibility to change the nature of the input or output, } \\
\text { or modus operandi (to employ substitutes) }\end{array}$ \\
\hline $\begin{array}{l}\text { The option to contract } \\
\text { /expand }\end{array}$ & $\begin{array}{l}\text { The capability of altering the capacity depending on } \\
\text { market conditions (low/high demand, intensity of } \\
\text { competition) }\end{array}$ \\
\hline The option to growth & $\begin{array}{l}\text { To create infrastructure and opportunities for future } \\
\text { expansion }\end{array}$ \\
\hline $\begin{array}{l}\text { The option to stage/ } \\
\text { compound option }\end{array}$ & To break up investment into incremental conditional steps \\
\hline
\end{tabular}


Table 3: Cost and Value of the Shadow and Real Options

\begin{tabular}{|c|c|c|}
\hline & Shadow option (SO) & Real option (RO) \\
\hline Premium (P) & $\begin{array}{l}\mathrm{P}_{\mathrm{SO}} \\
\text {-The cost of the entrepreneurial } \\
\text { resource that launches the process. } \\
\text {-Organizational Slack } \\
\text {-Cost of additional training, } \\
\text { without a direct link to } \\
\text { productivity. }\end{array}$ & $\begin{array}{l}\mathrm{P}_{\mathrm{RO}} \\
\text {-If follows the exercise of the } \\
\text { shadow option, the exercise price } \\
\text { and the premium of the shadow } \\
\text { option }\left(\mathrm{P}_{\mathrm{SO}}+\mathrm{K}_{\mathrm{SO}}\right) \text {. } \\
\text {-If the firm does not have the } \\
\text { previous shadow option, at least } \mathrm{S} \text {, } \\
\text { given through dynamic transaction } \\
\text { costs. }\end{array}$ \\
\hline Exercise price $(\mathrm{K})$ & $\begin{array}{l}\text { KSO } \\
\text {-Cost of convincing decision maker } \\
\text { to spend financial resources to } \\
\text { search and tie raw resources. } \\
\text { - Cost of monitoring the employee. }\end{array}$ & $\begin{array}{l}\mathrm{K}_{\mathrm{RO}} \\
\text { Cost to acquire the necessary } \\
\text { assets to enter production (plant, } \\
\text { workers...) }\end{array}$ \\
\hline Gain if exercise (S) & $\begin{array}{l}\mathrm{S}_{\mathrm{SO}} \\
\text { The value of best use of the new } \\
\text { combination of resources. }\end{array}$ & $\begin{array}{l}\mathrm{S}_{\mathrm{RO}} \\
\text { Present value of future cash flows } \\
\text { generated. }\end{array}$ \\
\hline $\begin{array}{l}\text { Value of the option } \\
\text { (V) }\end{array}$ & $\begin{array}{l}\mathrm{V}_{\mathrm{SO}} \\
\text { The value of the shadow option is } \\
\text { greater than the gain } \mathrm{S} \text { because it } \\
\text { incorporates the strategic } \\
\text { possibilities of the future. }\end{array}$ & $\begin{array}{l}\mathrm{V}_{\mathrm{RO}} \\
\text { As calculated by traditional real } \\
\text { option evaluation models } \\
\text { (uncertainty on demand, further } \\
\text { development etc...) }\end{array}$ \\
\hline
\end{tabular}


Figure 1: The Revisited Option Chain (initial work by Bowman/Hurry, 1993,p. 764)

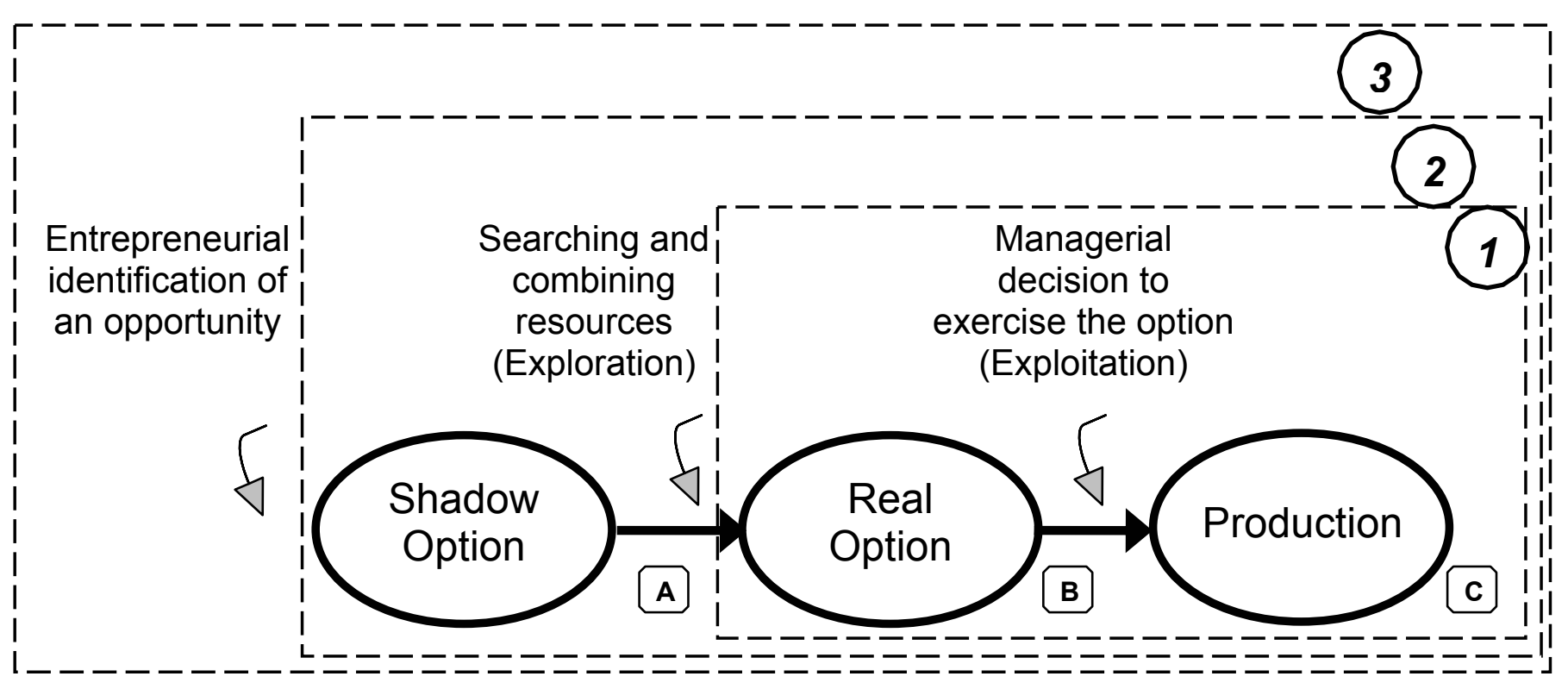




\section{Documents de travail du BETA}

2000-01 Hétérogénéité de travailleurs, dualisme et salaire d'efficience. Francesco DE PALMA, janvier 2000.

2000-02 An Algebraic Index Theorem for Non-smooth Economies. Gaël GIRAUD, janvier 2000.

2000-03 Wage Indexation, Central Bank Independence and the Cost of Disinflation. Giuseppe DIANA, janvier 2000.

2000-04 Une analyse cognitive du concept de « vision entrepreneuriale ». Frédéric CRÉPLET, Babak MEHMANPAZIR, février 2000.

2000-05 Common knowledge and consensus with noisy communication. Frédéric K৫SSLER, mars 2000.

2000-06 Sunspots and Incomplete Markets with Real Assets. Nadjette LAGUÉCIR, avril 2000.

2000-07 Common Knowledge and Interactive Behaviors : A Survey. Frédéric KCESSLER, mai 2000.

2000-08 Knowledge and Expertise : Toward a Cognitive and Organisational Duality of the Firm. Frédéric CRÉPLET, Olivier DUPOUËT, Francis KERN, Francis MUNIER, mai 2000.

2000-09 Tie-breaking Rules and Informational Cascades : A Note. Frédéric KESSLER, Anthony ZIEGELMEYER, juin 2000.

2000-10 SPQR : the Four Approaches to Origin-Destination Matrix Estimation for Consideration by the MYSTIC Research Consortium.

Marc GAUDRY, juillet 2000.

2000-11 SNUS-2.5, a Multimoment Analysis of Road Demand, Accidents and their Severity in Germany, 1968-1989.

Ulrich BLUM, Marc GAUDRY, juillet 2000.

2000-12 On the Inconsistency of the Ordinary Least Squares Estimator for Spatial Autoregressive Processes.

Théophile AZOMAHOU, Agénor LAHATTE, septembre 2000.

2000-13 Turning Box-Cox including Quadratic Forms in Regression. Marc GAUDRY, Ulrich BLUM, Tran LIEM, septembre 2000.

2000-14 Pour une approche dialogique du rôle de l'entrepreneur/managerdans l'évolution des PME : I'ISO comme révélateur ...

Frédéric CRÉPLET, Blandine LANOUX, septembre 2000.

2000-15 Diversity of innovative strategy as a source of technological performance.

Patrick LLERENA, Vanessa OLTRA, octobre 2000.

2000-16 Can we consider the policy instruments as cyclical substitutes ?

Sylvie DUCHASSAING, Laurent GAGNOL, décembre 2000. 
2001-01 Economic growth and CO2 emissions : a nonparametric approach.

Théophile AZOMAHOU, Phu NGUYEN VAN, janvier 2001.

2001-02 Distributions supporting the first-order approach to principal-agent problems.

Sandrine SPÆETER, février 2001.

2001-03 Développement durable et Rapports Nord-Sud dans un Modèle à Générations Imbriquées : interroger le futur pour éclairer le présent.

Alban VERCHÈRE, février 2001.

2001-04 Modeling Behavioral Heterogeneity in Demand Theory.

Isabelle MARET, mars 2001.

2001-05 Efficient estimation of spatial autoregressive models.

Théophile AZOMAHOU, mars 2001.

2001-06 Un modèle de stratégie individuelle de primo-insertion professionnelle.

Guy TCHIBOZO, mars 2001.

2001-07 Endogenous Fluctuations and Public Services in a Simple OLG Economy. Thomas SEEGMULLER, avril 2001.

2001-08 Behavioral Heterogeneity in Large Economies.

Gaël GIRAUD, Isabelle MARET, avril 2001.

2001-09 GMM Estimation of Lattice Models Using Panel Data : Application. Théophile AZOMAHOU, avril 2001.

2001-10 Dépendance spatiale sur données de panel : application à la relation Brevets-R\&D au niveau régional.

Jalal EL OUARDIGHI, avril 2001.

2001-11 Impact économique régional d'un pôle universitaire : application au cas strasbourgeois.

Laurent GAGNOL, Jean-Alain HÉRAUD, mai 2001.

2001-12 Diversity of innovative strategy as a source of technological performance.

Patrick LLERENA, Vanessa OLTRA, mai 2001.

2001-13 La capacité d'innovation dans les regions de l'Union Européenne.

Jalal EL OUARDIGHI, juin 2001.

2001-14 Persuasion Games with Higher Order Uncertainty.

Frédéric K৫SSLER, juin 2001.

2001-15 Analyse empirique des fonctions de production de Bosnie-Herzégovine sur la période 1952-1989.

Rabija SOMUN, juillet 2001.

2001-16 The Performance of German Firms in the Business-Related Service Sectors : a Dynamic Analysis.

Phu NGUYEN VAN, Ulrich KAISER, François LAISNEY, juillet 2001.

2001-17 Why Central Bank Independence is high and Wage indexation is low.

Giuseppe DIANA, septembre 2001.

2001-18 Le mélange des ethnies dans les PME camerounaises: l'émergence d'un modèle d'organisation du travail.

Raphaël NKAKLEU, octobre 2001. 
2001-19 Les déterminants de la GRH des PME camerounaises.

Raphaël NK AKLEU, octobre 2001.

2001-20 Profils d'identité des dirigeants et stratégies de financement dans les PME camerounaises. Raphaël NKAKLEU, octobre 2001.

2001-21 Concurrence Imparfaite, Variabilité du Taux de Marge et Fluctuations Endogènes.

Thomas SEEGMULLER, novembre 2001.

2001-22 Determinants of Environmental and Economic Performance of Firms : An Empirical Analysis of the European Paper Industry.

Théophile AZOMAHOU, Phu NGUYEN VAN et Marcus WAGNER, novembre 2001.

2001-23 The policy mix in a monetary union under alternative policy institutions and asymmetries. Laurent GAGNOL et Moïse SIDIROPOULOS, décembre 2001.

2001-24 Restrictions on the Autoregressive Parameters of Share Systems with Spatial Dependence. Agénor LAHATTE, décembre 2001.

2002-01 Strategic Knowledge Sharing in Bayesian Games : A General Model. Frédéric KESSLER, janvier 2002.

2002-02 Strategic Knowledge Sharing in Bayesian Games : Applications.

Frédéric KESSLER, janvier 2002.

2002-03 Partial Certifiability and Information Precision in a Cournot Game. Frédéric KESSLER, janvier 2002.

2002-04 Behavioral Heterogeneity in Large Economies.

Gaël GIRAUD, Isabelle MARET, janvier 2002.

(Version remaniée du Document de Travail n²001-08, avril 2001).

2002-05 Modeling Behavioral Heterogeneity in Demand Theory.

Isabelle MARET, janvier 2002.

(Version remaniée du Document de Travail n²001-04, mars 2001).

2002-06 Déforestation, croissance économique et population : une étude sur données de panel. Phu NGUYEN VAN, Théophile AZOMAHOU, janvier 2002.

2002-07 Theories of behavior in principal-agent relationships with hidden action.

Claudia KESER, Marc WILLINGER, janvier 2002.

2002-08 Principe de précaution et comportements préventifs des firmes face aux risques environnementaux.

Sandrine SPÆTER, janvier 2002.

2002-09 Endogenous Population and Environmental Quality.

Phu NGUYEN VAN, janvier 2002.

2002-10 Dualité cognitive et organisationnelle de la firme au travers du concept de communauté. Frédéric CRÉPLET, Olivier DUPOUËT, Francis KERN, Francis MUNIER, février 2002.

2002-11 Comment évaluer l'amélioration du bien-être individuel issue d'une modification de la qualité du service d'élimination des déchets ménagers?

Valentine HEINTZ, février 2002. 
2002-12 The Favorite-Longshot Bias in Sequential Parimutuel Betting with Non-Expected Utility Players.

Frédéric K৫SSLER, Anthony ZIEGELMEYER, Marie-Hélène BROIHANNE, février 2002.

2002-13 La sensibilité aux conditions initiales dans les processus individuels de primo-insertion professionnelle : critère et enjeux.

Guy TCHIBOZO, février 2002.

2002-14 Improving the Prevention of Environmental Risks with Convertible Bonds.

André SCHMITT, Sandrine SPAETER, mai 2002.

2002-15 L'altruisme intergénérationnel comme fondement commun de la courbe environnementale à la Kuznets et du développement durable.

Alban VERCHÈRE, mai 2002.

2002-16 Aléa moral et politiques d'audit optimales dans le cadre de la pollution d'origine agricole de l'eau.

Sandrine SPÆETER, Alban VERCHÈRE, juin 2002.

2002-17 Parimutuel Betting under Asymmetric Information.

Frédéric KESSLER, Anthony ZIEGELMEYER, juin 2002.

2002-18 Pollution as a source of endogenous fluctuations and periodic welfare inequality in OLG economies.

Thomas SEEGMULLER, Alban VERCHÈRE, juin 2002.

2002-19 La demande de grosses coupures et l'économie souterraine.

Gilbert KENIG, juillet 2002.

2002-20 Efficiency of Nonpoint Source Pollution Instruments with Externality Among Polluters : An Experimental Study.

François COCHARD, Marc WILLINGER, Anastasios XEPAPADEAS, juillet 2002.

2002-21 Taille optimale dans l'industrie du séchage du bois et avantage compétitif du bois-énergie : une modélisation microéconomique.

Alexandre SOKIC, octobre 2002.

2002-22 Modelling Behavioral Heterogeneity.

Gaël GIRAUD, Isabelle MARET, novembre 2002.

2002-23 Le changement organisationnel en PME : quels acteurs pour quels apprentissages ?

Blandine LANOUX, novembre 2002.

2002-24 TECHNOLOGY POLICY AND COOPERATION : An analytical framework for a paradigmatic approach.

Patrick LLERENA, Mireille MATT, novembre 2002.

2003-01 Peut-on parler de délégation dans les PME camerounaises ?

Raphaël NKAKLEU, mars 2003.

2003-02 L'identité organisationnelle et création du capital social: la tontine d'entreprise comme facteur déclenchant dans le contexte africain.

Raphaël NKAKLEU, avril 2003.

2003-03 A semiparametric analysis of determinants of protected area.

Phu NGUYEN VAN, avril 2003. 
2003-04 Strategic Market Games with a Finite Horizon and Incomplete Markets.

Gaël GIRAUD et Sonia WEYERS, avril 2003.

2003-05 Exact Homothetic or Cobb-Douglas Behavior Through Aggregation.

Gaël GIRAUD et John K.-H. QUAH, juin 2003.

2003-06 Relativité de la satisfaction dans la vie : une étude sur données de panel.

Théophile AZOMAHOU, Phu NGUYEN VAN, Thi Kim Cuong PHAM, juin 2003.

2003-07 A model of the anchoring effect in dichotomous choice valuation with follow-up. Sandra LECHNER, Anne ROZAN, François LAISNEY, juillet 2003.

2003-08 Central Bank Independence, Speed of Disinflation and the Sacrifice Ratio. Giuseppe DIANA, Moïse SIDIROPOULOS, juillet 2003.

2003-09 Patents versus ex-post rewards : a new look.

Julien PÉNIN, juillet 2003.

2003-10 Endogenous Spillovers under Cournot Rivalry and Co-opetitive Behaviors. Isabelle MARET, août 2003.

2003-11 Les propriétés incitatives de l'effet Saint Matthieu dans la compétition académique.

Nicolas CARAYOL, septembre 2003.

2003-12 The 'probleme of problem choice': A model of sequential knowledge production within scientific communities.

Nicolas CARAYOL, Jean-Michel DALLE, septembre 2003.

2003-13 Distribution Dynamics of $\mathrm{CO}_{2}$ Emissions.

Phu NGUYEN VAN, décembre 2003.

2004-01 Utilité relative, politique publique et croissance économique.

Thi Kim Cuong PHAM, janvier 2004.

2004-02 Le management des grands projets de haute technologie vu au travers de la coordination des compétences.

Christophe BELLEVAL, janvier 2004.

2004-03 Pour une approche dialogique du rôle de l'entrepreneur/manager dans l'évolution des PME : I'ISO comme révélateur ...

Frédéric CRÉPLET, Blandine LANOUX, février 2004.

2004-04 Consistent Collusion-Proofness and Correlation in Exchange Economies.

Gaël GIRAUD, Céline ROCHON, février 2004.

2004-05 Generic Efficiency and Collusion-Proofness in Exchange Economies.

Gaël GIRAUD, Céline ROCHON, février 2004.

2004-06 Dualité cognitive et organisationnelle de la firme fondée sur les interactions entre les communautés épistémiques et les communautés de pratique..

Frédéric CRÉPLET, Olivier DUPOUËT, Francis KERN, Francis MUNIER, février 2004.

2004-07 Les Portails d'entreprise: une réponse aux dimensions de l'entreprise «processeur de connaissances ».

Frédéric CRÉPLET, février 2004. 
2004-08 Cumulative Causation and Evolutionary Micro-Founded Technical Change: A Growth Model with Integrated Economies.

Patrick LLERENA, André LORENTZ, février 2004.

2004-09 Les CIFRE : un outil de médiation entre les laboratoires de recherche universitaire et les entreprises.

Rachel LÉVY, avril 2004.

2004-10 On Taxation Pass-Through for a Monopoly Firm.

Rabah AMIR, Isabelle MARET, Michael TROGE, mai 2004.

2004-11 Wealth distribution, endogenous fiscal policy and growth : status-seeking implications.

Thi Kim Cuong PHAM, juin 2004.

2004-12 Semiparametric Analysis of the Regional Convergence Process.

Théophile AZOMAHOU, Jalal EL OUARDIGHI, Phu NGUYEN VAN, Thi Kim Cuong PHAM, Juillet 2004.

2004-13 Les hypothèses de rationalité de l'économie évolutionniste. Morad DIANI, septembre 2004.

2004-14 Insurance and Financial Hedging of Oil Pollution Risks.

André SCHMITT, Sandrine SPAETER, septembre 2004.

2004-15 Altruisme intergénérationnel, développement durable et équité intergénérationnelle en présence d'agents hétérogènes.

Alban VERCHĖRE, octobre 2004.

2004-16 Du paradoxe libéral-parétien à un concept de métaclassement des préférences.

Herrade IGERSHEIM, novembre 2004.

2004-17 Why do Academic Scientists Engage in Interdisciplinary Research ?

Nicolas CARAYOL, Thuc Uyen NGUYEN THI, décembre 2004.

2005-01 Les collaborations Université Entreprises dans une perspective organisationnelle et cognitive.

Frédéric CRÉPLET, Francis KERN, Véronique SCHAEFFER, janvier 2005.

2005-02 The Exact Insensitivity of Market Budget Shares and the 'Balancing Effect'.

Gaël GIRAUD, Isabelle MARET, janvier 2005.

2005-03 Les modèles de type Mundell-Fleming revisités.

Gilbert KOENIG, janvier 2005.

2005-04 L'État et la cellule familiale sont-ils substituables dans la prise en charge du chômage en Europe ? Une comparaison basée sur le panel européen.

Olivia ECKERT-JAFFE, Isabelle TERRAZ, mars 2005.

2005-05 Environment in an Overlapping Generations Economy with Endogenous Labor Supply : a Dynamic Analysis.

Thomas SEEGMULLER, Alban VERCHÈRE, mars 2005.

2005-06 Is Monetary Union Necessarily Counterproductive?

Giuseppe DIANA, Blandine ZIMMER, mars 2005.

2005-07 Factors Affecting University-Industry R\&D Collaboration : The importance of screening and signalling.

Roberto FONTANA, Aldo GEUNA, Mireille MATT, avril 2005. 
2005-08 Madison-Strasbourg, une analyse comparative de l'enseignement supérieur et de la recherche en France et aux États-Unis à travers l'exemple de deux campus.

Laurent BUISSON, mai 2005.

2005-09 Coordination des négociations salariales en UEM : un rôle majeur pour la BCE.

Blandine ZIMMER, mai 2005.

2005-10 Open knowledge disclosure, incomplete information and collective innovations.

Julien PÉNIN, mai 2005.

2005-11 Science-Technology-Industry Links and the 'European Paradox': Some Notes on the Dynamics of Scientific and Technological Research in Europe.

Giovanni DOSI, Patrick LLERENA, Mauro SYLOS LABINI, juillet 2005.

2005-12 Hedging Strategies and the Financing of the 1992 International Oil Pollution Compensation Fund.

André SCHMITT, Sandrine SPAETER, novembre 2005.

2005-13 Faire émerger la coopération internationale: une approche expérimentale comparée du bilatéralisme et du multilatéralisme.

Stéphane BERTRAND, Kene BOUN MY, Alban VERCHÈRE, novembre 2005.

2005-14 Segregation in Networks.

Giorgio FAGIOLO, Marco VALENTE, Nicolaas J. VRIEND, décembre 2005.

2006-01 Demand and Technology Determinants of Structural Change and Tertiarisation : An InputOutput Structural Decomposition Analysis for four OECD Countries.

Maria SAVONA, André LORENTZ, janvier 2006.

2006-02 A strategic model of complex networks formation.

Nicolas CARAYOL, Pascale ROUX, janvier 2006.

2006-03 Coordination failures in network formation.

Nicolas CARAYOL, Pascale ROUX, Murat YILDIZOGLU, janvier 2006.

2006-04 Real Options Theory for Lawmaking.

Marie OBIDZINSKI, Bruno DEFFAINS, août 2006.

2006-05 Ressources, compétences et stratégie de la firme : Une discussion de l'opposition entre la vision Porterienne et la vision fondée sur les compétences.

Fernand AMESSE, Arman AVADIKYAN, Patrick COHENDET, janvier 2006.

2006-06 Knowledge Integration and Network Formation.

Müge OZMAN, janvier 2006.

2006-07 Networks and Innovation : A Survey of Empirical Literature.

Müge OZMAN, février 2006.

2006-08 A.K. Sen et J.E. Roemer : une même approche de la responsabilité ? Herrade IGERSHEIM, mars 2006.

2006-09 Efficiency and coordination of fiscal policy in open economies.

Gilbert KOENIG, Irem ZEYNELOGLU, avril 2006.

2006-10 Partial Likelihood Estimation of a Cox Model With Random Effects : an EM Algorithm Based on Penalized Likelihood.

Guillaume HORNY, avril 2006. 
2006-11 Uncertainty of Law and the Legal Process.

Giuseppe DARI-MATTIACCI, Bruno DEFFAINS, avril 2006.

2006-12 Customary versus Technological Advancement Tests.

Bruno DEFFAINS, Dominique DEMOUGIN, avril 2006.

2006-13 Institutional Competition, Political Process and Holdup.

Bruno DEFFAINS, Dominique DEMOUGIN, avril 2006.

2006-14 How does leadership support the activity of communities of practice ?

Paul MULLER, avril 2006.

2006-15 Do academic laboratories correspond to scientific communities ? Evidence from a large European university.

Rachel LÉVY, Paul MULLER, mai 2006.

2006-16 Knowledge flows and the geography of networks. A strategic model of small worlds formation.

Nicolas CARAYOL, Pascale ROUX, mai 2006.

2006-17 A Further Look into the Demography-based GDP Forecasting Method.

Tapas K. MISHRA, juin 2006.

2006-18 A regional typology of innovation capacities in new member states and candidate countries. Emmanuel MULLER, Arlette JAPPE, Jean-Alain HÉRAUD, Andrea ZENKER, juillet 2006.

2006-19 Convergence des contributions aux inégalités de richesse dans le développement des pays européens.

Jalal EL OUARDIGHI, Rabiji SOMUN-KAPETANOVIC, septembre 2006.

2006-20 Channel Performance and Incentives for Retail Cost Misrepresentation.

Rabah AMIR, Thierry LEIBER, Isabelle MARET, septembre 2006.

2006-21 Entrepreneurship in biotechnology: The case of four start-ups in the Upper-Rhine Biovalley.

Antoine BURETH, Julien PÉNIN, Sandrine WOLFF, septembre 2006.

2006-22 Does Model Uncertainty Lead to Less Central Bank Transparency?

Li QIN, Elefterios SPYROMITROS, Moïse SIDIROPOULOS, octobre 2006.

2006-23 Enveloppe Soleau et droit de possession antérieure : Définition et analyse économique. Julien PÉNIN, octobre 2006.

2006-24 Le territoire français en tant que Système Régional d'Innovation.

Rachel LEVY, Raymond WOESSNER, octobre 2006.

2006-25 Fiscal Policy in a Monetary Union Under Alternative Labour-Market Structures. Moïse SIDIROPOULOS, Eleftherios SPYROMITROS, octobre 2006.

2006-26 Robust Control and Monetary Policy Delegation.

Giuseppe DIANA, Moïse SIDIROPOULOS, octobre 2006.

2006-27 A study of science-industry collaborative patterns in a large european university. Rachel LEVY, Pascale ROUX, Sandrine WOLFF, octobre 2006.

2006-28 Option chain and change management : a structural equation application.

Thierry BURGER-HELMCHEN, octobre 2006. 
2006-29 Prevention and Compensation of Muddy Flows : Some Economic Insights. Sandrine SPAETER, François COCHARD, Anne ROZAN, octobre 2006.

2006-30 Misreporting, Retroactive Audit and Redistribution. Sandrine SPAETER, Marc WILLINGER, octobre 2006.

2006-31 Justifying the Origin of Real Options and their Difficult Evaluation in Strategic Management. Thierry BURGER-HELMCHEN, octobre 2006.

La présente liste ne comprend que les Documents de Travail publiés à partir du $1^{\mathrm{er}}$ janvier 2000. La liste complète peut être donnée sur demande.

This list contains the Working Paper writen after January 2000, 1rst. The complet list is available upon request. 